\title{
THE TRAINING OF GRATEFULNESS IN IMPROVING LIFE MEANING OF CONVICTS AT CLASS 2 LPKA PEKANBARU
}

\author{
Vivik Shofiah, Khairunnas Rajab \\ Fakultas Psikologi UIN Suska Riau \\ Corresponding Author: khairunnasrajab@gmail.com
}

\begin{abstract}
Religious values need are very imporant for convicts at LPKA Class two Pekanbaru. Religion is an obvious influenced source in issuing the meaning of life to convicts. The research objective is to know how far the influence of gratefulness training in improving life meaning of convicts at LPKA class two Pekanbaru is.The researcher used experiment approaching pre and post-test control group designwith 23 control groupsand 23 treatment groups, anddata analysis independent sample t-test was obtained score $t=6,894(p<0,01)$. Average score from treatment group are higher $(23,057)$ than control group average $(15,6)$. It shows that life meaning of convicts who get gratefulness training are higher than convicts who don't join the training. With thus, it can be concluded that gratefulness training very influence significantly to the life meaning of convicts at LPKA class 2 Pekanbaru.
\end{abstract}

Keywords: Training, Gratefulness, Life Meaning, LPKA Convicts

\begin{tabular}{|c|c|c|c|c|}
\hline Submission & Review Process & Revised & Accepted & Published \\
\hline January 10, 2020 & $\begin{array}{c}\text { January 10, 2020- } \\
\text { April 15, 2020 }\end{array}$ & April 18, 2020 & April 18, 2020 & June 1, 2020 \\
\hline
\end{tabular}

\section{INTRODUCTION}

Psychological welfare and function of human life are important part of life meaning (Steger \& Frazier, 2005). Without the meaning of life, value, goal, and idealismin someone will appear a decision. Franklexplained that someone will feel meaninglessness if they don't struggle for their life meaning.If condition of meaninglessness happens continously, it will cause "noogenicneurosis", namely condition has no indicator of boring and apathetic (Sumanto, 2006).

Base on some explanations above, there are some questions about how someone's efforts to reach the meaning of lifeamong another difficult life problems like the life of convicts in penitentiary. Predicate as convicts make them difference with another people outside penitentiary. All convicts stay in narrow space. The meaning is the freedom of convicts become limited.
In penitentiary, convicts movement is very limited because all areas are restricted and signed by iron bars for inside and high wall with higher barbed wire than human's high around it for outside, and it makes convicts can not run away from penitentiary.Many convicts suffer with condition which exist in penitentiary. Narrow space makes convicts diificult to express what they want. All activities are managed and scheduled well, therefore convicts must obey the applicable rules. The situation becomes worst because there are over capacity room what makes convicts difficult to move.

Besides full pressure situation and activities with all rules and also over capacity space make convicts become stress, for example physical stress and psychology during stay at penitentiary, like warden insult by speaking impolitely and snap. It makes something worst to their mental (Interview with L, 2017).Various behaviors as a result of 
changing the mental condition of convicts can be seen from depressed behavior, preferring solitude, contemplating fate, not eager to run a life, not trusting for a better change in the future and thinking that life is not meaningful so that at finally the idea of suicide sometimes appears (Interview with H, 2017) .

The stressful situationsare had by the convicts during they stay in penitentiary, the loss of trust in a better future than now worsens the mental condition. The situation has an impact on the loss of direction and purpose in life due to the fading of person's spirituality in believing in God so that it leads to meaningless living situations (Muzio, 2006). Victor E. Frankl (Bastaman, 2007)

states that every individual hopes to be happy in his life, like convicts who have narrow space and movement.

Likewise, what convicts have in the Development Institute for Children (LPKA) Pekanbaru Class 2 can be found children aged less than 18 years who have meaningless cases. Refer to the results of research conducted by Shofiah and Angreini (2014) about the relationship between gratefulness and the life meaning of child convicts in childpenitentiaryclass 2bPekanbaru which explaining that there is a relationship between gratefulness and the life meaning of child convicts in child penitentiary class $2 b$ Pekanbaru.

This research is base on braden's assumption (Rakhmat,2004) which says that the meaning of person's life can be obtained from religiosity, one of this is gratitude. Grateful peoplewill find happiness and optimistic about having a meaningful life (Froh, Yurkewich, Kashdan, 2009) Referring to the above explanation that gratitude will create the meaning of life. Through gratefulness training, it is hoped that it can improve the life meaning of convicts, because in gratefulness training, there is a gratefulness planting and its benefits.
Emmons and McCullough (Patnani, 2012) give an explanation that one of the intervention techniques in positive psychology, namely gratefulness training, can be used to improve the meaningfulness of life.

Grateful Individuals will have an impact on positive affective experiences such as happiness and being able to enjoy life satisfaction, hopefully, and tendency to undergo mild depression, anxiety and jealousy (McCullough inLinley \& Joseph, 2004).

Gratefulness training will direct convicts to be able to see the positive values that exist in themselves in the midst of limitation conditions and deprivation, such as undergoing life happily, have a spirit, confident to the future with indicators of productive behavior and responsible in daily activities.

Emmons and McCullough Research (2003) explained that gratefullness is part of religious behavior related to the ability of someone to thank god. Their research results also explained that physical and psychological welfare was born of gratefulness. One of this when people make a gratefulness list on a weekly will feel their lifes better and confident in undergoing the next day. Another result, in just two months, the people who made the gratefulness list willl have rapid progress in achieving personal goals and objectives relating to academic, health and interpersonal relationships. Grateful people have more positive emotions, satisfaction in life, vitality, optimism, and low depression levels or stress.

Gratefulness give happiness so that negative emotions become reduced. GratefulPeople do not consider goods or materials very important as common property. They are not easily jealous and envious, but would rather share with others (Wicaksono, 2013). Gratefulpeople will always be happy to undergo their lifes and influence behavior 
afterwards. Otherwise, people who are less grateful will not be creative in ideas to be better and have a tendency to accept what they are or forced to do their jobs (Wicaksono, 2013). The Grateful effect becomes an attitude to accept the existing situation. Gratefulness is also a coping strategy. Someone will control the problems of life in to a positive direction (Arief\&Habibah, 2015).

Being grateful for life will give the relaxed effect ,happy mind, healthy physique, and maximum intrapersonal relationships (Emmons \& McCullough, 2003). In line with the research of Froh, Seffick, and Emmons (2008) grateful adults, and express it will be more optimistic, enjoy work energicly, and their lifes become meaningful than ungrateful people.

Base on the explanations above, the hypothesis in this research is about gratefulness training in improving the life meaning of convicts in LPKA class 2 Pekanbaru.

\section{RESEARCH METHOD}

This research used quasi-experiment design with pretest-posttest control group design. The subjects were convicts in LPKA Class 2 Pekanbaru totaling 46 people, divided into 23 control groups and 23 treatment groups with characteristics:

1. Islam

2. Teenagers (13-17 years)

3. Able to read and write

4. Ready to follow all training sessions

The research data were collected using a scale of meaningfulness of life which include components of the life meaning, freedom of will, and meaningful life will with a reliability of 0.89 .
Table 1.

Blue Print of Life Meaning Scale

\begin{tabular}{lll}
\hline Components & Favorable & Unfavorable \\
\hline Freedom of Will & $1 ; 4 ; 5 ; 19$ & $17 ; 18 ; 20 ; 26$ \\
\hline Meaningful Life & $2 ; 9 ; 14 ; 16 ;$ & $3 ; 7 ; 10 ; 23 ;$ \\
Will & $21 ; 22 ; 25$ & 24 \\
\hline Life Meaning & $6 ; 11 ; 12$ & $8 ; 13 ; 15$ \\
\hline Total & 14 & 12 \\
\hline
\end{tabular}

Gratefulness training is a form of psychological intervention by giving understanding and skills to convicts to be able identifying the virtues that they get and realize there are another sources outside there for these goodness so that they can be applied to improve their gratefulness abilities.

The training was arranged based on the three grateful functions of McCullough and Emmons (2002) and how to train the grateful abilities of Emmons (2005), namely :

1. Grateful as moral barometer function, with the ways :

\subsection{Apply the gratefulness}

Through four approach steps cognitive behavioral to learn gratefulness, namely :
a. Identifying ungrateful thoughts
b. Formulate thoughts that support grateful
c. Replace ungrateful thoughts with thoughts that support grateful
d. Translating the feelings that exist in yourself becomeovert behavior

1.2.Intervention and strategy enrich grateful

A grateful experience can enrich a positive mood than just thinking, analyzing and writing about grateful. Individuals should realize the purpose when make grateful intervention in the sense that they only know the purpose of grateful, how the activity can attract their desire to practice it. 
2. Grateful as moral motive function, with the steps :

2.1.Create a grateful journal

Asking the subject to create grateful journal that contains notes that make him feel more grateful. This activity is carried out 4 times a week for 3 weeks. It will create a difference related to person's happiness.

2.2.Write a grateful letter

Write gratefulness on paper like a letter to someone who has contributed positively to life and read the letter he made to the intended person face to face.

3. Grateful as moral reinforce function, with the steps:

3.1.Count The Feeling Of Grateful and Express It

Count the found blessings as much as possible while doing activities that can make individuals feel grateful, like doing catharsis by shouting or saying loudly to nature related to the things loved in an individual's life.

3.2.Thanks to everyone for everything

Express with thanks to all those who have helped, do good to us or others. The expression of thanks can be in the form of a greeting to someone in the realtime or by letter.

During the experiment, the subjects were divided into 2 groups, namely the treatment and control groups. The treatment group got grateful training meanwhile the control group did not. Each group would be measured their life meaning twice, throughpretest and post test.

Hypothetical testing by using parametric statistical data analysis of the Independent Sample T Test.

\section{RESULTS AND DISCUSSION}

The results of the independent sample $t$ test analysis, the value of $\mathrm{t}=6,894 p \leq 0.01$. These results show that grateful training has a very significant effect on the meaning of life. The provisions for accepting and rejecting a hypothesis if the significance is below or equal to $0,01(p \leq 0,01)$ then the hypothesis is accepted (Sugiyono, 2007).

Table 2.

The Result of Independent Sample t-test

\begin{tabular}{ccc}
\hline $\begin{array}{c}\text { Independent } \\
\text { Sample t-test }\end{array}$ & $\begin{array}{c}\text { ExperimentGr } \\
\text { oup }\end{array}$ & $\begin{array}{c}\text { Control } \\
\text { Group }\end{array}$ \\
\hline $\mathrm{N}$ & 23 & 23 \\
Mean & 23.057 & 15.6 \\
Sig. & \multicolumn{2}{c}{0,000} \\
\hline Conclusion & $\begin{array}{c}\text { Significant } \leq 0.01 \text { indicates that there } \\
\text { is a very significant difference }\end{array}$ \\
\hline
\end{tabular}

This research is in accordance with the opinion of Braden (Rachmat, 2004) which says that the meaning of person's life can be obtained from religiosity, one of this namely grateful. Grateful People always find happiness and optimistic to get meaningful life (Froh, Yurkewich, Kashdan, 2009) This is in line with research conducted by Emmons \& McCullough (2003) which says that students who express grateful by write the goodness which they receive can improve relationships social, health, feel the satisfaction and happiness of life.

The meaning of life is the most important part that gives special value to someone, so it is worthy to be life goal (Bastaman, 2007). Frankl (1985) states that the meaning of life is not always related to religious issues, but often matter of life philosophy. Frankl also said that through work, find the beauty and truth, love with others and through human experiences can find or create the meaning in his life.

The meaning of the life of the convicts is found or created while he is in penitentiary 
through the three things that Frankl has stated, namely derived from creative values (CreativeValues), values of appreciation (ExperientialValues), and the values of attitude (Attitudinal Values).

The meaning of life is obtained by the convicts through what is given to the environment during their life in penitentiary (creative values), including by participating in all the mandatory activities in penitentiary. In addition, convicts choose to be active in activities such as scouts, farming, nurturing livestock, sports, playing music and religious studies than staying in the space.

The existence of convicts in penitentiary is a consequence of violating God's commands. Staying in penitentiary and still having the chance to live is an opportunity given by God to improve his life. This opportunity makes the convicts feel valuable after many mistakes that have been made during they live. In addition, convicts also begin to be discipline in praying to God so that their requests can be granted.

\section{CONCLUSION}

Referring to the research results that has been done, it can be concluded that:

1. There is an effect of gratefulness training in improving the life meaning of convicts in pentitentiaryclass 2Pekanbaru, with a value of $\mathrm{t}=6,894$, and a significance level0,000, $p \leq 0,01$.

2. The average score of the treatment group is higher (23.057) than the average score of the control group (15.6), it means that the life meaning of convicts who get grateful training is higher than convicts do not get training.

\section{REFERENCES}

Al-Munajjid, M. B. S. (2006). SilsilahAmalanHati. Ikhlas, Tawakkal, Optimis, Takut, Bersyukur, Ridha, Sabar, IntrospeksiDiri, Tafakkur,
Mahabbah, Taqwa, Wara. Bandung: IrsyadBaitus Salam.

Arief, MochamadFahmy\&Habibah, Nur. (2015). PengaruhStrategiAktivitas (BersyukurdanOptimis) terhadapPeningkatanKebahagiaanpada Mahasiswa S1 Pendidikan Guru SekolahDasar.SeminarPsikologi\&Kem anusiaan. Psychology Forum UMM, ISBN: 978-979-796-324-8

Bastaman, H.D. (2007). Logoterapi: PsikologiUntukMenemukanMaknaHid updanMeraihHidupBermakna. Jakarta: PT. Raja Grafindo

Emmons, RA. (2004). The Psychology Of Gratitude. New York: Oxford University Press.

Emmons, R.A.,\& McCullough, M.E. (2003). Counting Blessings versus Burdens : An Empirical Investigation of Gratitude and Subjective Wellbeing in Daily Life. Journal of Personality and Social Psychology, 84,377-389

Frankl, V. E. (1985). Man's search for meaning. revised and updated. New York: Washington Square Press.

Froh, J.J., Yurkewicz, C., \& Kashdan, T. B. (2008). Gratitude and subjective wellbeing in early adolescence: Examining gender diff erences. Journal of Adolescence xx 1-18.

Froh, J.J et all. (2007). Gratitude in Childern and Adolescent: Development, Assessment, And School-Based Intervention. School Psychology Forum: Research In Practice. Volume 2 Issue 1.

Linley P. Alex and Joseph, S.(2004). Positive Change Following Trauma and Adversity: A Review. Journal of Traumatic Stress, Vol. 17, No. 1, February 2004, pp. 11-21

Mc Cullough E. Michael and Emmons A. Robert. (2002).The Grateful Disposition: A Conceptual and 
Empirical Topography. Journal of Personality and Social Psychology. Vol. 82, No. 1, 112-127.

Patnani, M. (2012). Kebahagiaan pada Perempuan.Jurnal Psikogenesis. Vol. 1, No. 1, Desember 2012.

Puspitasari, T \& Nisfiannor, M. (2005). Komitmen Beragama dan Subjective Well-being. Jurnal Phronesis. Volume 7

Rakhmat, J. (2003). Psikologi Komunikasi. Jakarta: Remaja Rosdakarya.

Rakhmat, J. (2004).Psikologi Agama : Sebuah Pengantar. Bandung : Mizan

Steger F. Michael and Frazier, P.(2005). Meaning in Life: One Link in the Chain From Religiousness to WellBeing. Journal of Counseling Psychology. Vol. 52, No. 4, 574-582

Sumanto.(2006). Kajian Psikologis Kebermaknaan Hidup. Buletin Psikologi, Volume 14 Nomor 2, ISSN :0854-7108. 